\title{
Efficiency of Poultry Production in District Quetta Balochistan Pakistan
}

\author{
Sanaullah Noonari* $\quad$ Irfana Noor Memon \\ Assistant Professor, Department of Agricultural Economics, Faculty of Agricultural Social Sciences, Sindh \\ Agriculture University, Tandojam Pakistan
}

\begin{abstract}
This study was carried out by considering the importance of production of poultry farming in Balochistan Pakistan. The results showed there were 45.00 percent of the respondents farmers were rearing poultry birds on small scale 2000 birds , 33.34 percent of farmers were on the range 2001 to 4000 birds and 21.66 percent respondents were heaving up to 4000 birds on at their farms. Thus the selected poultry farmers on average per farm spent a total cost of production of Rs.551350.00. This included Rs.48000.00, Rs. 71350.00, Rs.157000.00, Rs.125000.00 and Rs.150000.00 on Farm rent/cost, Equipment Expenditure of farm, Expenditures Rearing, Labour charges and marketing costs respectively on capital inputs. The results of the return analysis indicated that production were an average per farm earned of Rs.960600.00 that included for Rs. 939600.00 on Sale of 900 birds weighing $1.5 \mathrm{~kg}$ each and Rs. 21000.00 sale of poultry manure obtained by the farmers of poultry. It's the result cleared from the table that each poultry farmer on an average per farm earned during study, Rs.409250.00 on net income, Rs.960600.00 on gross income and Rs. 551350.00 on total expenditure in the study area. The selected poultry farmers on an average per farm earned Rs. 960600.00non the inputs at Rs. 551350.00 in study area. The cost benefit ratio of the farming of poultry at 1:0.74 it means that the poultry farmers obtained Rs. 0.74 on each rupee invested by them in the study area.
\end{abstract}

Keywords: poultry, birds, capital inputs, average, manure, Balochistan

DOI: $10.7176 / \mathrm{JPID} / 54-02$

Publication date:May $31^{\text {st }} 2020$

\section{Introduction}

The poultry sector is one of the most organized and vibrant segments of the agriculture industry of Pakistan. Poultry Sector has contributed 1.3 percent in GDP during 2013-14 while its contribution in agriculture and livestock value added stood at $6.1 \%$ and $10.8 \%$ respectively. Poultry meat contributes $28.0 \%$ of the total meat production in the country. Poultry Industry is more than Rs. 200.00 billion. Poultry sector has shown a robust growth 8-10 percent annually which reflects its inherent potential. The poultry value added at current factor cost has increased from Rs. 121.7 billion (2012-13) to 130.7 billion (2013-14) showing an increase of $7.4 \%$ as compared to previous year. Export of live poultry and meat from Pakistan increased from Rs. 27 million in 200910 to Rs. 1.08 billion in 2010-11 and it decreased to Rs. 365 million in 2011-2012. Pakistan exports poultry and meat to Afghanistan, Iran, Vietnam and Hongkong. The last decade has seen significant investment in the industry, particularly in closed housing. Banks made net fresh loans of Rs. 4 billion in one year to October 2013 before distributing additional loans of another Rs.3 billion in the following year to October 2014 (GOP, 2014).

Poultry is a category of domesticated birds kept by humans for the purpose of collecting their eggs, or killing for their meat or feathers. These most typically are members of the super order Galloanserae (fowl), especially the order Galliformes (which includes chickens, quails and turkeys) and the family Anatidae (in order Anseriformes), commonly known as "waterfowl" (e.g. domestic ducks and domestic geese). Poultry comes from the French/Norman word poule, itself derived from the Latin word pullus, which means small animal. Poultry is the second most widely eaten meat in the world, accounting for about $30 \%$ of meat production worldwide (GFT, 2003).

Poultry farming industry is growing very rapidly in the Pakistan and its cities and its urban areas. Poultry farming culture in Pakistan and Asian countries is expanding Very rapidly and its rate of growth of commercial layer and meat producing (broiler) farms are increasing demand for proteins through poultry meat and eggs. If proper planning and management has not been taken care of then there is a chance of disease spread in the farms. So therefore we need to spread the planning and management for the better performance of the Poultry farming in Pakistan. In Pakistan poultry industry has made significant involvement to food production and its playing a vital role in the economy of the country Pakistan. Now with the passage of time commercial poultry production is concentrated around the largest urban centers in the other provinces of Pakistan like Sindh and Punjab and Firstly at Karachi, Lahore and it is now practically well spread all over the country. With the new researched planning farms we can improve the performance of this industry according to the Now the large scale investment and proper incentives have resulted in the establishment of Transportation comprising of 252 hatcheries with capacity to produce 346 million day old chicks per annum, 141 feed mills with the capacity to produce 2540 thousand tons of compounds feed per annum and 13154 poultry farms with the capacity to produce 98 million broilers (M.Farran, 2009). 
The poultry meat is the fastest growing component of global meet demand. The poultry sector growth is being driven by rising incomes, together with the emergence of vertically integrated poultry producers that have reduced consumer prices by lowering production and marketing costs. Integrated production by way of combining breeding, feed milling, contract rearing; a market transition from live birds to chilled and frozen products; and policies that help ensure supplies of competitively priced domestic or imported com and soybeans are keys to future poultry industry growth in India and in other developing countries (USDA, 2005) .

The poultry industry is providing job opportunities to more and more people. Chicken meat production is playing effective role in decreasing the gap of the animal protein availability and its requirement. The present study was therefore carried out to investigate the influence of various feed forms on production of broilers.

\section{Objectives}

1. To review present status of poultry production in Balochistan Pakistan.

2. To find out socioeconomic factors of poultry farmers in District Quetta.

3. To determine production costs, physical productivity and net return of poultry farms in Study area.

4. To identify the issues and suggest the policy measures for of poultry farms production.

\section{Methodology}

The study was carried out to investigate the production of poultry farming in Quetta district of Baluchistan province. The study focused on the production of poultry of poultry farming. Economics of production actually plays an important role in the production. It helps the farmers to use their available resources in a most efficient and profitable manner. It enables them to look into the various factors and to make adjustments in to get maximum returns and to minimize costs.

\section{Estimation of Farm inputs}

Farm resource utilization is the central to all discussions related to farm. It includes the study of farm resources, which contribute to both individual and society. The economic aspects of land resources utilization involve the objective of maximizing the net value of product, when land is used in combination with other resource.

The farm on sample farms was not perfectly homogenous. It varies in its inherent characteristics of productivity. Therefore farm inputs were aggregated on the basis of unit (farm) under poultry at the selected farms. Climate offers equal opportunity to all farmers in the farms and hence it may have very insignificant effect on the comparison of efficiency of farm resources. The estimating farm inputs for poultry farming on the sample farms, the following formula was used:

Fip $=($ Fs $\times$ Fr $)+($ Fs $\times$ Re $)$ Fs

Where,

Fip $=$ Farm input per unit of poultry

$\mathrm{Fr}=$ Farm rent per unit

$\mathrm{Re}=$ Rate of electricity charges

Fs $=$ Farm size

\section{Estimation of labour cost}

To compute labour costs used in the farming of poultry, labour engaged, number of days worked, wage rate paid per man per day employed along with working man and wage rate paid were investigated each farming carried out on the sample farms. In poultry farming were estimated by applying the following formula.

$\mathrm{Lip}=(\mathrm{Mn} \times \mathrm{Hc})+(\mathrm{Mwd} \times \mathrm{Wr}) / \mathrm{Fs}$

Where

Lip=Labour input per in poultry farm

$\mathrm{Mn}=$ Machine work hour

Hc=Hiring charges

$\mathrm{Mwd}=$ Man work days

$\mathrm{Wr}=$ Wage rate

Fs $=$ Farm size

\section{Measurement of capital inputs}

To compute the cost of production incurred by farmers on capital inputs and the items such as Chicken Hatchery, food, Spray chemicals, Fumigation etc. The quantities of these inputs used by farmers of poultry farming and the prices at which the inputs were purchased or acquired were investigated. The following formula was evolved to compute per unit cost on these inputs.

$\mathrm{Cpu}=(\mathrm{Qh} \times \mathrm{Pr})+(\mathrm{Qf}+\mathrm{Pr})+(\mathrm{Qc} \times \mathrm{Pr}) / \mathrm{Fs}$

Where

$\mathrm{Cpu}=$ Capital inputs per unit of poultry 
Qh=Quantity of Hatchery

$\mathrm{Pr}=$ Price per unit of inputs

$\mathrm{Qf}=$ Quantity of food

$\mathrm{Qc}=$ Quantity of Spray chemicals, Fumigation

Fs $=$ Farm size

Estimation of returns

While the produce retained by farmers for their home consumption was valued at prices prevailing in the area. The quantity of poultry marketed by the farmers was timed with prices they received at the time of disposal by using following formula:

$\mathrm{P}=$ Output price at wholesale level

$\mathrm{C}=$ Cost per unit produced

$\mathrm{Q}=$ Output of broiler or total live body weight

$\mathrm{TC}=$ Total cost of production.

Ip $=$ Input prices

\section{Results}

This study is based on primary data, which was collected from poultry farmers in district Quetta Balochistan. The study is described into three subsections:

\subsection{Age of farmers}

Table 1: Distributions of the respondents according to their age

\begin{tabular}{|l|c|c|}
\hline \multicolumn{1}{|c|}{ Age } & No. of farmers & Percentage \\
\hline 21-30 years & 12 & 20.00 \\
\hline $31-40$ years & 18 & 30.00 \\
\hline 41-50 years & 19 & 31.66 \\
\hline More than 50 years & 11 & 18.34 \\
\hline Total & 60 & 100 \\
\hline
\end{tabular}

Table-1 shows the distributions of the respondents with the percent of poultry farmer age group. In age group of 21-30 years, 20.00 percent, 31-40 years, 30.00 percent, $41-50$ years, 31.66 percent of poultry farmer age group. With more than 50 years old farmers, the percentage of poultry farmer age group 18.34 percent.

\subsection{Education level of farmers}

Table 2: Distribution of the respondent according to their education level

\begin{tabular}{|l|c|c|}
\hline \multicolumn{1}{|c|}{ Education level } & No. of farmers & Percentage \\
\hline Illiterate & 10 & 16.66 \\
\hline Primary & 15 & 25.00 \\
\hline Middle & 26 & 43.34 \\
\hline Matriculation & 8 & 13.34 \\
\hline Collage/University & 01 & 1.66 \\
\hline Total & 60 & 100.00 \\
\hline
\end{tabular}

Table-2 shows the distributions of the education of the respondents with the percent of poultry farmer education level. In education level 16.66 percent farmers were illiterate, while about 25.00 percent farmers were Primary level of education, 43.34 percent were middle, 13.34 percent matriculation and 1.66 percent bachelor/master education in the study area.

\section{3. size of farmers}

Table 3: Distributions of the respondents according to their family

\begin{tabular}{|l|c|c|}
\hline \multicolumn{1}{|c|}{ Family size } & No. of farmers & Percentage \\
\hline 5-10 Members & 28 & 46.66 \\
\hline 11-15 Members & 23 & 38.34 \\
\hline More than 15 Members & 09 & 15.00 \\
\hline Total & 60 & 100.00 \\
\hline
\end{tabular}

Table-3 shows about the family size of the respondent. Their family size of 5-10 members and they had 46.66 percent of the poultry farmer 11-15 Members and they had 38.34 percent of the poultry farmer and more than 15 Members they had 15.00 percent of the poultry farmer. 


\subsection{Farming experience of farmers}

Table 4: Distributions of the respondents according to their farming experience

\begin{tabular}{|l|c|c|}
\hline \multicolumn{1}{|c|}{ Farming Experience } & No. of farmers & Percentage \\
\hline Up to 10 years & 08 & 13.34 \\
\hline $11-20$ years & 25 & 41.66 \\
\hline $21-30$ years & 15 & 25.00 \\
\hline Above 30 years & 12 & 20.00 \\
\hline Total & 60 & 100.00 \\
\hline
\end{tabular}

Table-4 shows relationship between farming experience of poultry farmer. The respondents having farming experience of up to 10 years; they had 13.34 percent, 11-20 years of farming experience had 41.66 percent,21-30 years of farming experience possessed 25.00 percent of poultry farming. Similarly, farmers with more than 30 years of farming experience had 20.00 percent of poultry farming.

\subsection{Family Type of farmers}

Table 5: Distribution of respondents according to family type in the study area

\begin{tabular}{|l|c|c|}
\hline \multicolumn{1}{|c|}{ Family Type } & No. of farmers & Percentage \\
\hline Joint & 32 & 46.66 \\
\hline Extended & 6 & 10.00 \\
\hline Single & 22 & 43.33 \\
\hline Total & 60 & 100.00 \\
\hline
\end{tabular}

Table-5 shows that there were 46.66 percent were joint family system, 10.00 percent were extended family type and 43.33 percent were single family type of the poultry farmer.

\subsection{Hygienic}

Table 6: Distributions of respondents according to Hygienic farms

\begin{tabular}{|l|c|c|}
\hline \multicolumn{1}{|c|}{ Particulars } & No. of farmers & Percentage \\
\hline Good & 20 & 33.34 \\
\hline Satisfactory & 31 & 51.66 \\
\hline Poor & 09 & 15.00 \\
\hline Total & 60 & 100.00 \\
\hline
\end{tabular}

Table-6 shows about the respondents were categorized in four different categories on the basis of hygienic conditions on their poultry farms. That 33.34 percent farmer is rearing birds in good hygienic condition, 51.66 percent in satisfactory, 15.00 percent in poor hygienic condition.

\subsection{Disinfectants}

Table 7: Distributions of respondents according to Disinfectant methods

\begin{tabular}{|l|c|c|}
\hline \multicolumn{1}{|c|}{ Particulars } & No. of farmers & Percentage \\
\hline Spray chemicals & 31 & 51.66 \\
\hline Fumigation & 23 & 38.34 \\
\hline Not practiced & 06 & 10.00 \\
\hline Total & 60 & 100.00 \\
\hline
\end{tabular}

Table-7 shows that 51.66 percent poultry farmers spray chemicals for disinfection purpose. It also presents that 38.34 percent farmers used to fumigate for disinfection purpose. It was also reported that 10.00 percent farmers do not exercise any such practice to disinfect their farm.

\subsection{Farm Size/Capacity of farm}

Table 8: Size /capacity of poultry farm in the study area

\begin{tabular}{|l|c|c|}
\hline \multicolumn{1}{|c|}{ Farm Capacity } & No. of farmers & Percentage \\
\hline Up to 2000 birds & 27 & 45.00 \\
\hline 2001 to 4000 birds & 20 & 33.34 \\
\hline Above 4000 birds & 13 & 21.66 \\
\hline Total & 60 & 100.00 \\
\hline
\end{tabular}

Table- 8 shows that there were 45.00 percent of the respondents farmers were rearing poultry birds on small scale 2000 birds , 33.34 percent of farmers were on the range 2001 to 4000 birds and 21.66 percent respondents were heaving up to 4000 birds on at their farms. 


\subsection{Farm rent}

Table 9: Farm rent of poultry farm in the study area

\begin{tabular}{|c|c|}
\hline \multicolumn{1}{|c|}{ Particulars } & Mean \\
\hline Loading/ Unloading & 48000.00 \\
\hline
\end{tabular}

Table- shows that on an average per Farm rent farmer spent a sum of Rs. 48000.

4.10.Equipment Expenditure

Table 10: Equipment Expenditure of poultry farm in the study area

\begin{tabular}{|l|c|c|}
\hline \multicolumn{1}{|c|}{ Particulars } & Rate per unit & Mean \\
\hline 2 electric/gas/Diesel brooders & 500.00 & 1000.00 \\
\hline 10 chick guard sheets & 200.00 & 2000.00 \\
\hline 20 chick feeders / trays & 80.00 & 1600.00 \\
\hline 20 chick drinkers & 85.00 & 1700.00 \\
\hline 40 round feeders & 150.00 & 6000.00 \\
\hline 10 automatic drinkers & 450.00 & 4500.00 \\
\hline 1 buckets & 350.00 & 350.00 \\
\hline 1 wheel barrow & 2300.00 & 2300.00 \\
\hline 1 electric water pump & 5000.00 & 5000.00 \\
\hline 1 spray pump & 7500.00 & 7500.00 \\
\hline 16 lying nest & 2000.00 & 32000.00 \\
\hline 18 curtains & 400.00 & 7200.00 \\
\hline Miscellaneous expenditure & Total Rs. & 2000.00 \\
\hline \multicolumn{2}{|c|}{} & 71350.00 \\
\hline
\end{tabular}

Table-10 shows that on an average per equipment expenditure of poultry farm spent a sum of Rs. 71350.00 in study area.

\subsection{Expenditures Rearing}

Table 11: Expenditures rearing of poultry farm in the study area

\begin{tabular}{|l|c|c|}
\hline \multicolumn{1}{|c|}{ Particulars } & Rate per unit & Mean \\
\hline Cost of 1000 day-old chicks(1000) & Rs.75/each & 75000.00 \\
\hline Cost of feed 6 kg / bird for (1000) & Rs.40/kg & 40000.00 \\
\hline Cost of vaccination \& medication & Rs.28/bird & 28000.00 \\
\hline Elect: \& fuel consumption charges & Rs.2000/month & 12000.00 \\
\hline Miscellaneous expenditure & Total Rs. & 3000.00 \\
\hline \multicolumn{2}{|r|}{} & 157000.00 \\
\hline
\end{tabular}

Table-11 shows that on an average per expenditures rearing of poultry farm spent a sum of Rs. 157000.00 in study area.

\subsection{Labour charges}

Table 12: Labour Inputs of poultry farm in the study area

\begin{tabular}{|l|c|c|}
\hline \multicolumn{1}{|c|}{ Particulars } & Rate per unit & \multicolumn{1}{c|}{ Mean } \\
\hline upervisor (1/2 monthly visit) & 600.00 & 12000.00 \\
\hline eedings/monthly & 5000.00 & 25000.00 \\
\hline leaning/monthly & 5000.00 & 25000.00 \\
\hline atchmen & 5000.00 & 25000.00 \\
\hline rinkers/monthly & 5000.00 & 25000.00 \\
\hline praying (weekly spray) & 300.00 & 13000.00 \\
\hline \multicolumn{2}{|r|}{ Total Rs. } & 125000.00 \\
\hline
\end{tabular}

Table-12 shows that Rs 125000.00 on an average per farm poultry farmer spent labour cost of production. This included Rs. 12000.00 on Supervision (weekly visit), Feedings Rs. 25000.00, Cleaning Rs. 25000.00, Watchmen Rs. 25000.00, Drinkers Rs. 25000.00 and spraying (weekly spray) Rs. 13000.00 respectively in the study area. 


\subsection{Marketing costs}

Table 13: Marketing cost of poultry farm in the study area

\begin{tabular}{|l|c|c|}
\hline \multicolumn{1}{|c|}{ Particulars } & Rate per unit & Mean \\
\hline Loading/ Unloading & $12000.00 /$ monthly & 35000.00 \\
\hline Transportation & $15000.00 /$ monthly & 80000.00 \\
\hline \multicolumn{3}{|r|}{ Total Rs. } \\
\hline
\end{tabular}

Table-13 shows that each selected poultry farmers in study area on average per farm spent a sum of Rs. 150000.00. This included Rs. 35000.00 for loading, Rs. 80000.00 for transportation and Rs. 35000.00 of unloading.

\subsection{Total Expenditures}

Table 14: Total Expenditures of poultry farm in the study area

\begin{tabular}{|l|c|}
\hline Particulars & Mean \\
\hline Farm rent/cost & 48000.00 \\
\hline Equipment Expenditure of farm & 71350.00 \\
\hline Expenditures Rearing & 157000.00 \\
\hline Labour charges & 125000.00 \\
\hline Marketing costs & 150000.00 \\
\hline Total Rs. & 551350.00 \\
\hline
\end{tabular}

Table-14 showed that the selected poultry farmers in study area on average per farm spent a total cost of production of Rs.551350.00. This included Rs.48000.00, Rs. 71350.00, Rs.157000.00, Rs.125000.00 and Rs. 150000.00 on Farm rent/cost, Equipment Expenditure of farm, Expenditures Rearing, Labour charges and marketing costs respectively on capital inputs.

\subsection{Physical Productivity/ Revenue Productivity}

Table 15: Physical / Revenue Productivity of poultry farm in the study area

\begin{tabular}{|l|c|c|}
\hline \multicolumn{1}{|c|}{ Particulars } & Rate per unit & Mean \\
\hline Sale of 8700 spent hens weighing $1.5 \mathrm{~kg}$ each & $108.00 / \mathrm{kg}$ & 939600.00 \\
\hline Sale of poultry manure & $3000.00 /$ trolley & 21000.00 \\
\hline \multicolumn{2}{|c|}{ Total Rs. } & 960600.00 \\
\hline
\end{tabular}

Table-15 shows that the each selected poultry farmer in study area on an average per farm earned of Rs.960600.00 that included for Rs. 939600.00 on Sale of 900 birds weighing $1.5 \mathrm{~kg}$ each and Rs. 21000.00 sale of poultry manure obtained by the farmers of poultry.

\subsection{Net farm income}

Table 16: Net farm income of poultry farm in the study area

\begin{tabular}{|l|c|}
\hline \multicolumn{1}{|c|}{ Particulars } & Mean \\
\hline Gross income (Rs) A & 960600.00 \\
\hline Total expenditure (Rs) B & 551350.00 \\
\hline Net Income (Rs) A-B=C & 409250.00 \\
\hline
\end{tabular}

Table-16 it's the result cleared from the table that each poultry farmer on an average per farm earned during study, Rs.409250.00 on net income, Rs.960600.00 on gross income and Rs. 551350.00 on total expenditure in the study area.

\subsection{Productivity ratio}

Table 17: Productivity ratio of poultry farm in the study area

\begin{tabular}{|c|c|c|c|}
\hline Particulars & Gross income (Rs) & Total expenditure (Rs) & Cost benefit ratio \\
\hline Farm & $(\mathrm{A})$ & $(\mathrm{B})$ & $\mathrm{A} / \mathrm{B}=\mathrm{C}$ \\
\hline 1 & 960600.00 & 551350.00 & $1: 1: 74$ \\
\hline
\end{tabular}

Table-17 show that the selected poultry farmers on an average per farm earned Rs. 960600.00non the inputs at Rs. 551350.00 in study area. Therefore they availed input output ratio of 1:1:74 from poultry farming in the study area; it means that with the investment of Rs.1.00 in poultry enterprises they yielded Rs. 1.74 in the study area. 


\subsection{Cost Benefit ratio}

Table 18: Cost Benefit ratio of poultry farm in the study area

\begin{tabular}{|c|c|c|c|}
\hline Particulars & Net income (Rs) & Total expenditure (Rs) & Cost benefit ratio \\
\hline Farm & $(\mathrm{A})$ & $(\mathrm{B})$ & $\mathrm{A} / \mathrm{B}=\mathrm{C}$ \\
\hline & & & $1: 0.74$ \\
& 409250.00 & 551350.00 & \\
\hline
\end{tabular}

Table -18 shows that the cost benefit ratio of the farming of poultry at 1:0.74 it means that the poultry farmers obtained Rs. 0.74 on each rupee invested by them in the study area.

\section{Conclusion and suggestions}

The study on "Economic analysis of poultry production in district Quetta Balochistan" revealed that broiler production is remunerative and offers full scope for employment generation when it is operated on a large scale. The economic analysis in terms of cost and returns, Net Present value (NPV), Benefit-cost ratio (BCR) indicated that the broiler farming is economically viable. It was also concluded that broiler farms are give higher yields. There is also a great scope for broiler industry's development on a large scale as there is huge domestic and foreign demand for broilers. Broilers can also become an important source of foreign exchange earner. The poultry sector is dependent on external sources in the terms of brood. In addition, investments in manufacturing mentioned products in Balochistan should be encouraged.

Following suggestions have been made keeping in view the problem, related to production and marketing of broilers faced by the producers of the study area.

$>$ The poultry farmers should increase the farm size of their business as they can get the more profit of scale.

$>$ An input was the major cost of production of poultry so, it is recommended to have proper management to increase the income.

$>$ High yielding breeds of poultry birds should be made available to poultry farmer through modern breeding techniques.

$>$ The concerned department should come forward to train poultry farmers on up-keeping their flock on scientific lines.

$>$ More farmers should be motivated to venture in this trade as broiler production is having high economic returns.

$>$ Marketing of broilers through proper channels needs to be encouraged.

$>$ Export facilities for broilers need to be strengthened as there is great demand of dressed broiler in Gulf countries.

$>$ Creation of broiler marketing board, which can take care of both, marketing of output as well as timely supply of inputs.

$>$ An extension activity needs to be strengthened, so as to guide the poultry farmers about latest happenings around the world related to poultry industry.

\section{References}

Abedullah, A. Maqbool and K. Bukhsh. 2007. Issues and economics of poultry production: a case study of Faisalabad, Pakistan. Pakistan Vet. J., 2007, 27(1): 25-28.

Ahmad Sarfraz, TahirZahoorChohan and Ikram Ali. 2008. Economic Analysis of Poultry (Broiler) Production in Mirpur, Azad Jammu KashmirPak. j. life soc. sci. 6(1): 4-9.

Amos T.T. 2006. Analysis of Backyard Poultry Production in Ondo State, Nigeria. International Journal of Poultry Science 5 (3): 247-250.

Alabi, R.A. and M.B. Aruna 2006.Technical Efficiency of Family Poultry Production in Niger Delta, Nigeria, Journal Central European Agriculture 6(4) 531-538.

Ahmad, 2008. Economic Analysis of Poultry (Broiler) Production in Mirpur, Azad JammuKashmir. Pakistan Journal of Social Sciences. 6(1): 4-9.

Ali, M.D. 2002.Nigeria poultry and products-poultry update. USDA, Foreign Agriculture service: GAIN report N12025.

Bayaner A. 1999. Economic Analyses of Laying hen Farms in Çorum Province (in Turkish). research in- stitute for Agricultural Economics, Publication no. 23, Ankara.

BBI. 2013. The Poultry processing and marketing in the Balochistan province. Report to FAO. http: bbi.gob.pk

Bell 2008 Technical, allocative and economic efficiency of commercial poultry farms in Bangladesh. World poultry science, $66, \mathrm{pp} .465-476$.

Bamiro, OM, Philip, DO, Momoh, SO 2006.Vertical Integration and Production Efficiency in Poultry (egg) Industry in 
Ogun and Oyo States, Nigeria. Int. J. Poultry Sci. 2: 1164- 1171.

M.Farran, 2009. Marketing of poultry and poultry products in Jhang Tehsil, M.Sc. Thesis, Faculty of Agric. Econ. Univ. of Agric. Faisalabad.Govt. of AJK. 2002. Report of P\&D Deptt. of Azad Jammu \& Kashmir on Population Census: $49 \mathrm{p}$.

Ezeh, (2012). Technical Efficiency in Poultry Broiler Production in Umuahia Capital Territory of Abia State, Nigeria. Greener Journal of Agricultural Sciences. Vol. 2(1), pp. 001-007

Ekunwe, PA, Soniregun, 2000. Median Scale Battery Cage System of Poultry Egg Production in Edo State, Nigeria Benson Idahosa University Benin City, Edo State, Nigeria. Asian Network for Scientific Information, 2007. Evbuomwan,

FAO,2009 "Food and Agriculture Organization article on eggs". Fao.org. Archived from the original on 2004-0307. Retrieved 2010-01-10.Fanatico et al., 2007,Changing dynamics in global poultry production. World poultry, 25 (08), pp.1-2.

Gous, R. M. 2007. Predicting nutrient responses in poultry: future challenges. India. European Journal of Social Sciences. 26(1): 122-131.

GoP,2014.Pakistan Economic Survey2013-14.Finance Division, Government of Pakistan, Islamabad.

GOP,2012.Agricultural Statics of Pakistan 2011-12.Minstary of food, Agriculture and Livestock Division, Government of Pakistan, Islamabad.

GFT, 2003. Productivity Growth, Technical Progress and Efficiency Change in Industrialized Countries, America Economic Rev., pp: 66- 83.

Jamali et al., 2011. Economic Analysis of Poultry (Broiler) Production in Mirpur, Azad Jammu Kashmir. Pak. J. Life soc. Sci. 6(1): 4-9.

Maqbool, A. 2002. Marketing system of poultry inFaisalabad, M. Sc. Thesis; Univ. of Agric,Faisalabad.

Maiduguri, 2011). Office Memo File Murtala, A 2004. Cost and Return Analysis of Poultry Egg Marketing inBauchi Metropolis, Nigeria In: Ibrahim, A., Shettima, B.G., Sulumbe, I.M. and Abdullahi, H. A. (eds). Economic Analysis of

Mobley and Kahan, 2007.Technical, allocative and economies of broiler farms in the central region of Saudi Arabia: data envelopment analysis approach. Saudi social of agricultural science, Saudi Arabia,1(2),pp. 73-99.

Mohsin, A. Q., Riaz. R., Asad.S and Mushtaq. A. 2008. Profitability Analysis of Broiler Production in Rawalpindi District. Pakistan Journal of Agri. Sci. Vol. 45(4)

Mohanty S., Rajendran K. 2003. 2020 Vision for Indian Poultry Industry. International Journal of Poultry Science, 2(2): 139-143.

Ollinger M., MacDonald J.M., Madison M. 2005. Technological Change and Economies of Scale in U.S. Poultry Processing. American Journal of Agricultural Economics, 87(1): 116-129.

Ohajianya,D.O. and N.N.O. Oguoma. 2009. Effects of floor space on Economic Efficiency of Broiler Producers in Imo State. Journal of Economics Theory 3(1): 1-3.

Ojo, SO 2003. Productivity and Technical Efficiency of Poultry Egg Production in Nigeria. Int. J. Poultry Sci. 2(6): 459464, 2003.

Oyedipe E.O. 2000.Optimizing the Potential of Livestock Production in Nigeria: Improving Nutritional Standard. Agric. Vet. int. 1 (2) 19-20.

Poapongsakorn, 2005. Poultry processing and marketing in the Bangkok metropolitan area. Report to FAO, AGAL.

Stewart RM. Durnian JM. Briggs MC 2006. "'Here's egg in your eye": a prospective study of blunt ocular trauma resulting from thrown eggs". Emergency Medicine Journal 23 (10): 756-758. doi:10.1136/emj.2006.035501. PMC 2579593. PMID 16988300.

Sarfraz Ahmad, TahirZahoorChohan and Ikram Ali. 2009. Economic Analysis of Poultry (Broiler) Production in Mirpur, Azad Jammu Kashmir. Pak. J. Life soc. Sci. 6(1): 4-9.

SMEDA,(2011)Measurement of farm level efficiency of Broiler Production in Uyo, Akwa Ibom State, Nigeria. World Journal of Agricultural Sciences 5(S): 832-836.

Singh Varinder Pal, V. K. Sharma, M.S. Sidhu and H.S. Kingra. 2010. Broiler Production in Punjab:An Economic Analysis. 23(3):315-324.

Udoh, E. J., \& Etim, N. A. 2009. Measurement of farm level efficiency of broiler production in Uyo, Aka IbomState, Nigeria. World agricultural Sciences, 5(S), 832-

UFT 2007: registrations of Under Secretariat of Foreign Trade. Under Secretariat of Foreign Trade, Ankara.

USDA. 2005 Thailand poultry and products annual 2005. GAIN report number TH5092, September. Washington DC, Foreign agricultural service, United States department of agriculture.

Van P.L.M. and Bondt N. 2003: impact of EU council Directive 99/74/Ec' Welfare of Laying hens' on the competitiveness of the EU Egg industry.

Yusuf, S.A. and O. Malomo 2002.Technical Efficiency of Poultry Egg Production in Ogun State: A Data Envelopment Analysis (DEA) approach. International journal of poultry science 6(9):627-629.

Zaibun, et al. 2013Technical Efficiency of Poultry Production in Ogun State. International Journal of Poultry Science 6 (9): 622-629. 